\title{
Karın ağrısı etiyolojisinde ne var? Bir makroamilazemi vakası
}

\author{
What is the etiology of abdominal pain? A case of macroamylasemia
}

\author{
Furkan Bertuğ ÇETiN', Süleyman DOLU1', Yasin ŞAHINTÜRK', Seyit UYAR' , Feyzi BOSTAN', Ayhan Hilmi ÇEKIN² \\ Sağlık Bilimleri Üniversitesi Antalya Eğitim ve Araştırma Hastanesi, ${ }^{1}$ Iç Hastalıkları Kliniği, ${ }^{2}$ Gastroenteroloji Kliniği, Antalya
}

\begin{abstract}
Karın ağrısı ile başvuran ve akut pankreatit düşünülen hastalardan öncelikle istenmesi gereken laboratuvar tetkikleri arasında amilaz ve lipaz yer alır. Ancak amilaz pankreatit dışında birçok sistemik hastalık nedeniyle, kullanılan ilaçlara bağlı olarak ya da cerrahi ve travma sonrası yükselebilir. Karın ağrısı ile başvuran amilaz düzeyi yüksek olduğu halde pankreatit olmayan hastalarda makroenzimler akla gelmelidir. Makroamilazemi, makroenzimlerin ilk tanımlanmış olanı ve en sık görülenidir. Bu hastalarda başka bir nedenle oluşabilen karın ağrısı yanlışlıkla pankreatit düşündürebilir ve bu durum tanıda ve tedavide karışıkığa neden olabilir. Makroamilazeminin erken tespit edilmesi yanlış akut pankreatit tanısını, gereksiz tedavileri ve yapılacak olan invaziv işlemleri önler. Bu çalışmada 2 aydır epigastrik bölgede olan karın ağrısı, şişkinlik, bulantı ve kusma şikayetleri ile presente olan 81 yaşındaki bir makroamilazemi vakası sunuldu.
\end{abstract}

Anahtar kelimeler: Makroamilazemi, akut pankreatit, makroenzimler
Serum amylase and lipase levels should be tested in patients admitted to the hospital with abdominal pain to rule out acute pancreatitis. Serum amylase levels may also increase in many systemic diseases and both postsurgical and posttraumatic conditions. Elevated serum amylase levels also may be the side effects of certain drugs. Macroamylasemia should be considered in patients with elevated amylase levels but without any intraabdominal pathologies or drug interactions. Macroamylasemia was the first described and most frequently seen of the macroenzyme types. In these patients, abdominal pain might emerge due to another reason and may incorrectly be referred to as pancreatitis. This situation may cause confusion and lead to both incorrect diagnosis and subsequent inappropriate treatment. Early detection of macroamylasemia not only prevents the misdiagnosis of pancreatitis but also avoids unnecessary treatment or invasive procedures. In this case, we report an 81-year-old macroamylasemia patient who presented with complaints of epigastric pain, blorrhea, nausea, and vomiting for two months.

Key words: Macroamylasemia, acute pancreatitis, macroenzymes

mellitus ve ilaçlar gibi bir çok neden de amilaz yükseliği yapabilir (2). Vücuttan atııımı da böbrekler yoluyla olduğu için böbrek yetmezliği de amilaz yüksekliği yapan nedenlerden birisidir (4).

Makroenzimler; plazmada bulunan enzimlerin veya izoenzimlerinin yüksek molekül ağırlıkı formlarına verilen isimdir (5). Bu makroenzimler rutin laboratuvar tetkikleri ile normal kan değerlerinin daha yüksek ölçülmesine ve yanlış teşhisler konulmasına neden olabilirler. Bu yüzden semptomu olmayan ya da semptomları ile serum kan değerleri arasında ilişki olmayan ve süreklilik gösteren yüksek serum enzim düzeyleri olan hastalarda makroenzim varlığı düşünülmelidir ve amilaz/kreatin klirens oranın hesaplanması makroamilazemi tanısında yol göstericidir (5).

\section{OLGU}

Seksen bir yaşında bayan hasta, yaklaşık 2 aydır epigastrik bölgede olan karın ağrısı, şişkinlik, bulantı ve kusma 
şikayetleri ile hastanemiz acil servisine başvurdu. Yapılan fizik muayenede epigastrik hassasiyeti vardı, defans/ rebound yoktu, barsak sesleri normoaktifti. Acil serviste yapılan laboratuvar tetkiklerinde lökosit (WBC): 4.900/ $\mathrm{mm}^{3}$, hemoglobin $(\mathrm{Hgb}): 9,1 \mathrm{~g} / \mathrm{dL}$, eritrosit sedimantasyon hızı (ESR): 99 mm/saat, C-reaktif protein (CRP): 24,60 $\mathrm{mg} / \mathrm{L}$, kan üre nitrojeni (BUN):14 mg/dl, kreatinin: 0,9 $\mathrm{mg} / \mathrm{dL}$, aspartat aminotransferaz (AST): $19 \mathrm{U} / \mathrm{L}$, alanin aminotransferaz (ALT): $4 \mathrm{U} / \mathrm{L}$, gama glutamil transpeptidaz (GGT): $9 \mathrm{U} / \mathrm{L}$, alkalen fosfataz (ALP): $44 \mathrm{U} / \mathrm{L}$, amilaz: 1018 U/L, lipaz: 2 U/L olması üzerine çekilen batın ultrasonografi (USG)'de safra kesesinin opere intrahepatik safra yollarının normal ve koledok çapının 8 mm olduğu saptandı. Hasta akut pankreatit ön tanısılla gastroenteroloji servisine yatırıldı. Öyküsünde ağrısının 2 aydan beri epigastrik bölgede lokalize olduğu, ara ara şiddetlenip azaldığı, yemeklerle ilişkisi olmadığı ve zaman zaman bulantı kusmanın eşlik ettiği öğrenildi. Hastanın ishal, kabızlık ya da rektal kanama şikayeti yoktu. Özgeçmişinde kronik obstruktif akciğer hastalığı ve geçirilmiş kolesistektomi öyküsü vardı. Düzenli olarak salbutamol, tiotropium bromür, flutikazon propionat kullanıyordu. Ayrıca hastaya 2 ay önce başka bir hastanede koledokolitiazis ön tanısıyla endoskopik retrograt kolanjiopankreatografi (ERCP) yapılmış ve safra çamuru ekstrakte edilmişti. 2 aydır karın ağrısı için pantaprozol tablet kullanmakta olan hastanın medikal ya da bitkisel başka ilaç kullanımı yoktu.

Akut pankreatit etiyolojisi için bakılan kan trigliserid ve kalsiyum düzeyi normaldi. Yapılan servis abdominal ultrasonografide normal sonografik bulgular saptandı. Pankreatit tanısını ve etiyolojisini değerlendirmek amacıyla çekilen batın bilgisayarlı batın tomografide intrahepatik safra yolları ve koledok içerisinde yaygın hava dansiteleri ve genişleme olup, koledok çapı pankreas başı lokalizasyonunda yaklaşık $11 \mathrm{~mm}$ olarak ölçüldü. Ayrıca batın tüm kadranlarda özellikle kolon segmentlerinde daha belirgin olmak üzere distansiyon vardı ve özellikle çekumda, rektosigmoid bölgede, çıkan kolon lokalizasyonunda duvar kalınlaşmaları saptandı. Olası koledok patolojisi için manyetik rezonans-kolanjiyopankreatografi (MRCP) çekildi. MRCP'de koledok distal kesimde $7 \mathrm{~mm}$ çapında, T2A sekansında hipointens dolum defektine neden olan lezyon izlendi. Bu nedenle ERCP yapıldı ve koledok normal olarak değerlendirildi.

Görüntülemelerinde pankreatit ile ilgili bulgu saptanmayan, MRCP bulguları geçirilmiş ERCP' ye bağlı hava dansiteleri ile uyumlu olan, ağrısı tipik pankreatit ağrısı ile uyumlu olmayan hastaya epigastrik ağrısı nedeniyle Intravenöz (IV) proton pompa inhibitörü (PPI) tedavisi verildi. Ağrısı 3. günde gerileyen hastaya üst gastrointestinal endoskopi yapıldı ve normal olarak tespit edildi. Batın tomografide saptanan patolojik bulgular nedeniyle yapılan kolonoskopi de normaldi.

Ağrısı geçmesine rağmen amilaz değerleri hep yüksek seyreden hastaya (Tablo 1) parotis ve submandibular bezleri değerlendirmek amacıyla ultrasonografi yapıldı ve birkaç adet milimetrik reaktif lenf nodu dışında patolojik bulgu saptanmadı. Mezenter iskemi açııından yapılan mezenter doppler ultrasonografide tüm damarsal yapılarda normal akım izlendi. Ovaryan-fallop kisti, pelvik inflamatuvar hastalık açısından kadın hastalıkları ve doğum bölümü tarafından değerlendirildi; jinekolojik patoloji tespit edilmedi. Multiple myelom açısından gönderilen serum ve idrar immünfiksasyon elektroforezi normal olarak sonuçlandı. Yapılan görüntülemelerinde amilaz yüksekliğine neden olabilecek solid bir tümör tespit edilmedi. Tüm bu değerlendirmeler neticesinde hastada makroamilazemi olabileceği düşünüldü ve amilaz/kreatinin klirensine oranını belirlemek amacıyla 24 saatlik idrarda ve serumda amilaz ve kreatinin değerleri çalışsıldı. İdrar amilazı $23.03 \mathrm{IU} / \mathrm{L}$, serum amilazı $887 \mathrm{IU} / \mathrm{L}$, idrar kreatinini $501.6 \mathrm{mg} / \mathrm{dl}$, serum kreatinini $1.17 \mathrm{mg} / \mathrm{dl}$ saptandı. Amilaz/kreatinin klirensi oranı \%0.05 (\%1.8-3.2) bulundu ve bu sonuç makroamilazemi lehine yorumlandı. Yakınmaları semptomatik tedavi ile geçen hasta taburcu edildi. Taburcu olduktan sonra takibine poliklinikten devam edilen hastanın amilaz değerleri yine yüksek olarak devam etti (Tablo 1). Hastanın polikliniğimizde halen tedavisi ve takibi devam etmektedir.

\section{TARTIŞMA}

Karın ağrısı ile gelen hastalarda amilaz yüksekliği saptanması durumunda ilk akla gelecek hastalık akut pankreatittir (3). Akut pankreatit tanısı tipik karın ağrısı, ami-

Tablo 1. Kan amilaz ve lipaz düzeyleri

\begin{tabular}{|l|c|c|c|c|c|c|} 
& \multicolumn{2}{|c|}{$\begin{array}{c}\text { Hastanın 3 Ay } \\
\text { Önceki Laboratuvarı }\end{array}$} & \multicolumn{2}{c|}{ Hastanın Serviste Yattı̆ı̆ı Süre Boyunca Olan Laboratuvarı } & $\begin{array}{c}\text { Hastanın } \mathbf{2} \text { Ay } \\
\text { Sonraki Laboratuarı }\end{array}$ \\
\hline & 26.01 .2015 & 09.04 .2015 & 11.04 .2015 & 16.04 .2015 & 20.04 .2015 & 15.06 .2015 \\
\hline Amilaz (U/L) & 465 & 1018 & 860 & 813 & 787 & 702 \\
\hline Lipaz (U/L) & 13 & 12 & 11 & 8 & 22 & 8 \\
\hline
\end{tabular}


laz veya lipaz yüksekliği ve görüntüleme yöntemlerinde pankreas hasarı bulgularından en az iki tanesinin olması ile konulmaktadır (6). Serum amilaz düzeyleri serebrovasküler hastalık, solunum ve kalp hastalıkları, ilaçlar, hepatobiliyer hastalıklar, diyabetes mellitus, peptik ülser, böbrek-over-gastrointestinal sistem maligniteleri, intra ve ekstraabdominal cerrahiler, travma, dislipidemi, feokromasitoma, multipl miyelom, organ transplantasyonları, enfeksiyonlar, kronik pankreatik kaynaklı patolojik olmayan hiperamilazemi ve ailesel hiperamilazemi gibi birçok durumda yüksek bulunabilmektedir (2) (Tablo 2).

Makroenzimler fizyolojik ya da patolojik durumlarda serumda bulunan yüksek molekül ağırlıklı komplekslerdir (2). Makroenzimler ilk kez 1964 yılında Wilding ve arkadaşları tarafından amilaz için tanımlanmıştır (4). Daha sonra lipaz, AST, ALT, kreatin kinaz (CK), GGT, ALP, asit fosfataz (AP) gibi enzimler için bu tanımlamalar kullanılmıştır $(4,5)$.

Makroamilazemi sağlıklı bireylerde en sık bildirilen makroenzim olmasına rağmen patogenezi hala tam olarak anlaşılamamıştır $(2,7)$. Makroamilazlar genellikle s-izoenzi- min immünglobin $G(\lg G)$ veya immünglobin $A(\lg A)$ ile oluşturduğu komplekslerdir ve \%92'sinde amilaz enzimi IgA tipi ile kompleks oluşturmaktadır $(2,7)$. Bu kompleks kappa ya da lambda hafif zincirler ile oluşur ve boyutları nedeniyle böbrek glomerüllerinden geçemezler ve kanda kalırlar (2). Ancak bu bağlanmanın niye ve nasıl olduğu, neden tüm enzimlerde olmadığı ve neden bazı kişilerde olduğu henüz net olarak bilinmemekle birlikte doğal ya da iyatrojenik iki farklı yolla oluştuğuna dair teoriler vardır (2).

Doğal yollarla oluşan makroamilazemi için en çok öne sürülen teori moleküler benzerlik teorisidir (4). Bu teoriye göre bir self antijenin yabancı bir antijene moleküler benzerliği nedeniyle ona karşı gelişen antikorla reaksiyon vermesi söz konusudur. Günlük diyetimiz içinde hayvansal gıdalarla birlikte amilaz gibi antijenleri de alıyoruz, dolayısıyla gerçekleşebilecek bir çapraz reaksiyon sonucu makroamilazemi oluşabilir. Ayrıca gastrointestinal sistemin mukozal yüzeyinde en çok immünoglobulin A bulunduğu için de makroamilazeminin neden en çok IgA tipi ile kompleks oluştuğu açıklanabilir. Diğer bir öne sürülen teori ise otoimmün hastalıklarda görülen bozulmuş immün

Tablo 2. Amilaz yüksekliği yapan nedenler

\begin{tabular}{|c|c|c|c|}
\hline Pankreas Hastalıkları & $\begin{array}{l}\text { Pankreatit } \\
\text { Pankreatit komplikasyonları } \\
\text { (psödokist, abse) } \\
\text { Travma } \\
\text { Ameliyat } \\
\text { ERCP } \\
\text { Duktal tıkanıklık } \\
\text { Pankreas kanseri } \\
\text { Kistik fibrozis }\end{array}$ & Jinekolojik Hastalıklar & $\begin{array}{l}\text { Ektopik gebelik rüptürü } \\
\text { Over veya fallop kistleri } \\
\text { Pelvik inflamatuvar hastalık }\end{array}$ \\
\hline Tükrük Bezi Hastalıkları & $\begin{array}{l}\text { Enfeksiyon } \\
\text { Travma } \\
\text { Radyasyon } \\
\text { Duktal tıkanıklık }\end{array}$ & Malignite & $\begin{array}{l}\text { Solid tümör (over, prostat, } \\
\text { akciğer, özofagus, meme ve } \\
\text { timus) } \\
\text { Multiple myelom } \\
\text { Feokromasitoma }\end{array}$ \\
\hline Gastrointestinal Hastalıklar & $\begin{array}{l}\text { Perfore veya penetre peptik ülser } \\
\text { Perfore bağırsak } \\
\text { Obstrükte bağırsak } \\
\text { Mezenterik iskemi } \\
\text { Apendisit } \\
\text { Kolesistit } \\
\text { Karaciğer hastalığı } \\
\text { Ciddi gastroenterit } \\
\text { Çölyak hastalığı }\end{array}$ & Diğer & $\begin{array}{l}\text { Böbrek yetmezliği } \\
\text { Alkol kullanımı } \\
\text { Makroamilazemi yanıklar } \\
\text { Asidoz (ketotik ve non-ketotik) } \\
\text { Gebelik } \\
\text { AIDS Serebral travma } \\
\text { Abdominal aort anevrizması } \\
\text { Anorexia nervosa, bulimia } \\
\text { Post-operasyon ilaç } \\
\text { Idiopatik double-balon } \\
\text { enteroskopi sonrası } \\
\text { Akut karaciğer yetmezliği }\end{array}$ \\
\hline
\end{tabular}


Tablo 3. Makroamilazemi çeşitleri

\begin{tabular}{|l|c|c|c|c|}
\hline & Serum Amilaz & Serum Lipaz & İdrar Amilaz & Amilaz/Kreatinin Klirensi \\
\hline Tip-1 & Artar & Normal & Düşük & Çok düşük \\
\hline Tip-2 & Artar & Normal & Düşük/Normal & Düşük \\
\hline Tip-3 & Normal & Normal & Normal & Düşük/Normal \\
\hline
\end{tabular}

tolerans teorisidir. Yani bireyin kendine ait antijenlerine (self-antijen) karşı reaksiyon oluşturmasıdır (4). Nar ve arkadaşlarının yaptığı bir olgu sunumunda çölyak hastalığı bulunan kişilerde, glutensiz diyetle makroamilazeminin kaybolduğunun gösterilmesi de bu teoriyi desteklemektedir (8). Bizim olgumuzda da otoimmün hastalık düşündürecek semptom ve fizik muayene bulgusu yoktu ve gönderilen otoantikorlar da negatif olarak saptandı.

Iyatrojenik makroamilazemi; amilazın enzim-substrat kompleksidir. IV olarak verilen glikoprotein ya da polisakkarit infüzyonu ile oluşur (9). Amilaz enzimi bu ürünlerin doğal substratına benzediğinden yüksek moleküler kütleye sahip kompleks oluştururlar ve oluşan bu kompleksler böbreklerden atılamaz ve serumda birikir (4).

Makroamilazeminin 3 tipi vardır (Tablo 3). Tip 1'de; artmış serum total amilazı, düşük amilaz/kreatinin klirensi oranı vardır. Tip 2'de; serum total amilazı artmış, amilaz/ kreatinin klirensi fazla düşmemiştir. Tip $3^{\prime}$ de ise serum amilazı normaldir (5). Bizim hastamız da Tip 1 makroamilazemi ile uyumluydu.

Amilaz renal yolla atılan bir enzimdir ve serum amilaz seviyelerindeki artış idrar amilaz aktivitesini artııı (2). Bu nedenle akut pankreatitli hastalarda idrar amilaz değeri de yükselir (2). Fraksiyone amilaz klirensi (amilaz/kreatinin klirens oranı) \%1,8-3,2 arasında bir değerdir. Makroamilazemi durumunda idrar amilaz düzeyi azalacağı için fraksiyone amilaz klirensi de azalır (10). Diğer hiperamilazemi nedenleri dışlanan bir hastanın fraksiyone amilaz klirensinin düşük olması makroamilazemi tanısını destekler. Bizim hastamızın da bakılan fraksiyone amilaz klirensi düşük olarak ölçüldü ve hastada herhangi bir renal patoloji olmadığı için bu durum makroamilazemi lehine yorumlandı.

Amilaz/kreatinin klirensi oranı da her makroamilazemili hastada doğru sonuç vermeyebilir (5). Ancak hastanın mevcut kliniği hala makroamilazemi düşündürüyorsa öncelikle protein elektroforezi yapılmalı ve buna göre değerlendirilmelidir (5). Polietilen glikol ile çöktürme testi, ısıya dayanıklıık testi, aktivasyon enerjisi ve amonyum sülfatla çözünürlük ve ELISA yöntemi bu aşamada kullanılabilecek diğer tarama testleridir (5). Ancak tarama testlerinden sonuç alınamazsa jel filtrasyon testi, immün elektroforez ve immün fiksasyon testlerine başvurulabilir (5). Bizim hastamızın idrar amilaz/kreatinin klerensi düşük olduğu için ileri incelemeye gerek yoktu ancak hiperamilazemi etiyolojisi için yapılan kan ve idrar immünfiksasyon elektroforezleri normal olarak tespit edildi.

Sonuç olarak bir tanının konulması ancak o tanının düşünülmesi ile olasıdır. Makroamilazemi, hiperamilazemi yapan nedenlerden biri olup, amilaz yüksekliği saptanan hastalarda eğer klinik, fizik muayene ve öncelikli yapılan görüntülemeler herhangi bir patolojiyi işaret etmiyorsa düşünülmesi gereken tanılardan biridir. Makroamilazeminin erken tespit edilmesi pankreatit tanısına yönelik yapılacak olan ileri tetkik ve tedavileri önleyecektir. Bir hastada makroamilazemi tanısı konulduğunda, bu sonuç hakkında hastaya ve yakınlarına bilgi verilmelidir. Böylece, kişiye herhangi bir şikayetle hastaneye başvurduğu zaman gereksiz ileri tetkik ve invaziv işlemlerin yapılmasını engelleyecektir.

\section{KAYNAKLAR}

1. Pekmezsi S. Akut pankreatitte yaklaşım ve tedavi. In: Göksoy E, Şentürk H. Hepato-Bilier Sistem ve Pankreas Hastalıkları. Sempozyum Dizisi. Ocak 2002;s.239-62.

2. Yalnız M, Asoğlu M, Demirel U, et al. A case of hyperamylasemia: Macroamylasemia? Review of the literature. J Clin Exp Invest 2011;2:98-101.

3. Almiş $H$, Bucak IH, Çelik V, et al. İyi bilinen, ancak ilk düşünülmeyen bir tanı: Makroamilazemi. İzmir Dr. Behçet Uz Çocuk Hast. Dergisi 2015;5:78-9.

4. Türkçapar N, Özden A. Makroenzimler. Güncel Gastroenteroloji Dergisi. 2006;10:269-72.

5. Özaslan E, Sivri B. Makroenzimler ve makroamilazemi. Güncel Gastroenteroloji Dergisi 1998;2:163-9

6. Tenner S, Baillie J, DeWitt J, Vege SS; American College of Gastroenterology. American College of Gastroenterology guideline: Management of acute pancreatitis. Am J Gastroenterol 2013;108:140015. Erratum in; Am J Gastroenterol 2014;109:302.

7. Rabsztyn A, Green PH, Berti I, et al. Macroamylasemia in patients with celiac disease. Am J Gastroenterol 2001;96:1096-100.

8. Nar H, Uyanıkoğlu A, Aydoğan T, Yenice Y. A celiac patient presenting with hyperamylasemia: A case report. Akademik Gastroenteroloji Dergisi. 2013;12:30-1.

9. Durr HK, Bode C, Krupinski R, Bode $\mathrm{CH}$. A comparison between naturally occuring macroamylasemia and macroamylasemia induced by hydroxyethyl-starch. Eur J Clin Invest 1978;8:189-91.

10. Levitt MD. Clinical use of amylase clearence and isoamylase measurements. Mayo Clin Proc 1979:54:428-431. 